\title{
Financial Literacy Education in the United States
}

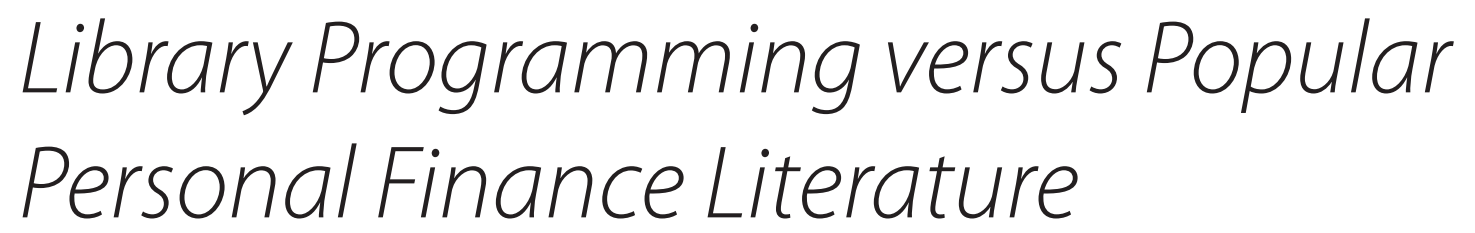

Ashley E. Faulkner

\begin{abstract}
Ashley E. Faulkner (ashleyf@ princeton.edu) is Interdisciplinary Quantitative Research Librarian at Princeton University Library, Princeton, New Jersey.
\end{abstract}

Reference \& User Services Quarterly, vol. 56, no. 2, pp. 116-25 ๑) 2016 American Library Association. All rights reserved.

Permission granted to reproduce for nonprofit, educational use.
It is essential that librarians providing financial literacy programming understand how their programming ties in with the available personal finance literature. Consequently, this article intends to explore the interplay between the differing audiences, content and goals addressed by the popular personal finance genre and financial literacy library programming respectively. The author will explore how library programming and the most popular financial literacy resources compare and contrast, and address how overlap, and the surprising degree of separation between these mediums, will impact the financial literacy education accessible to various demographic groups and the role library programming may play in the movement to come.

I $\mathrm{n}$ the United States, financial literacy is a term used almost ubiquitously in a negative context: for instance, in discussing that among young Americans with a college education only 49 percent can answer a handful of very basic financial literacy questions correctly or that, as reported by the Financial Industry Regulatory Authority (FINRA), only 14 percent of Americans overall can answer a full five personal finance questions correctly. ${ }^{1}$ This lack of financial literacy is perhaps why household spending in the United States is consistently ranked among the highest of the OECD nations, while US personal savings rates are consistently in the bottom 50 percent of OECD nations. ${ }^{2}$ While standard financial wisdom recommends saving at least 10 percent of one's gross income, the average personal savings rate in the United States, as of May 2015, was only 5.1 percent. ${ }^{3}$ While there are likely many factors contributing to poor household financial indicators in the US, improved financial literacy is one potential mean of addressing these concerns.

The United States does not address this topic widely in $\mathrm{K}-12$ schooling. Though 43 US states now include personal finance somewhere in their K-12 standards, only six states require student testing of these concepts, and thus the topic is not widely addressed. ${ }^{4}$ Topics not addressed in formal schooling can be addressed through personal study, or taught at home. A problem arises, however, when there are multiple generations of financially illiterate citizens. "Most of us learn about money from our parents," points out personal finance guru Robert T. Kiyosaki in his book Rich Dad, Poor Dad. "[But] what can a poor parent tell their child about money?"5 Americans are left in a situation where schools don't teach financial 
literacy, parents often can't teach financial literacy, yet most realize, as famous financial pundit Suze Orman recounts to her readers, "You will never truly be powerful in life until you are powerful with your own money." Someone needs to address financial literacy education nationwide. As civic anchor institutions and the undisputed home of democratic education in the United States, libraries have become a common resource to fulfill this need. ${ }^{7}$

Attention to this issue was slow to develop in the public library world, however. While the history of what one might today term financial literacy education in libraries dates back to the early twentieth century, authors did not begin to discuss financial literacy in library science literature (the particular term and all it encompasses) until the early 2000s, when the multi-literacies movement began and instead of a focus on literacy as a general term encompassing many skills, individual skills were highlighted via individually named literacies. The term financial literacy in particular arose first in education research journals, and even in popular personal finance literature, before being studied by library science researchers. The earliest library science articles to explore financial literacy focused on this skillset in light of consumer education and rights in the financial industry, likely as an echo of the government's growing concern for consumer protection, as evidenced by programs like the Federal Reserve Bank of Chicago's Money Smart Week program which began in 2002, or the establishment of the Financial Education and Literacy Commission by Congress in 2003. ${ }^{8}$

The study of financial literacy by library science researchers has intensified in the intervening years and libraries have begun to explore a myriad of ways to address this public education need. Numerous scholarly articles have explored both the increased need for financial literacy skills and the practicality of providing programming and reference assistance in both public and academic libraries. ${ }^{9}$ In 2010, Molly A. Wolfe-Hayes's article "Financial Literacy and Education: An Environmental Scan" discussed where financial literacy fit into the multiliteracies movement and provided an overview of ongoing financial literacy activities. ${ }^{10}$ In 2012, Margaret Monsour's article "Libraries Innovate with New Financial Literacy Programs" reviewed the success of the first five years of the Smart Investing@Your Library programming (a partnership grant program between the American Library Association and FINRA). ${ }^{11}$ And in 2013, Catherine Arnott Smith and Kristin Eschenfelder reported the results of a series of quantitative field studies examining librarian perceptions of the challenges involved in providing financial literacy services, the perceptions of partner organizations and individuals in providing these services, and an exploration of financial literacy services and web resources offered by a sample of public libraries. ${ }^{12}$

Within the recent increase in financial literacy research, however, one area that has remained almost entirely unexamined is the relationship between financial literacy library programming, and library financial literacy collections. While this seems an instinctive interplay to explore, programming has held the vast majority of LIS scholarly attention, with very few exceptions, and thus far no major works have focused predominantly on the relationship between programming and library resources. As evidence of the strong professional preoccupation with programming, consider: The American Library Association's (ALA) Reference and User Services Section's (RUSA) Financial Literacy Education in Libraries: Guidelines and Best Practices for Service mentions the word "collection" precisely one time, encouraging librarians to keep their financial literacy content up to date. For that matter, though the word "content" appears in the document twenty-seven times, only four uses of the term refer to personal finance resources, while the other uses of the term mainly refer to the information being imparted in programming. ${ }^{13}$

There is nothing wrong with a strong interest in programming, but to achieve the greatest public impact, library programming and library collections should ideally work hand-in-hand. If libraries are to continue to provide financial literacy programming, librarians need to understand how this programming ties together with their library's personal finance resources. Librarians addressing financial literacy should consider how programming and collections are similar or dissimilar regarding:

- Their intended target audiences;

- Content covered; and,

- The goals addressed and achieved by both means of education.

It is essential that librarians providing financial literacy programming understand how their programming ties in with the available personal finance literature so that between programming and content, they might guide their users toward intelligent debate or the further exploration of particular topics. This article explores the interplay between the differing audiences, content, and goals addressed by the popular personal finance genre and financial literacy library programming respectively. The paper examines how library programming and the most popular financial literacy resources compare and contrast and addresses how degrees of overlap and separation may impact libraries, and their patrons, as the financial literacy movement continues onward.

\section{CASE STUDY}

Exploring the entirety of US library financial literacy programming and the full personal finance literary genre would be impractical. This study focuses on representative offerings to act as proxies for an exploration of financial literacy "programming" and "collections" generally. To explore financial literacy library programming, the author studied RUSA's Financial Literacy Education in Libraries: Guidelines and Best Practices for Service, as this document serves as a guide to financial literacy programming initiatives. ${ }^{14}$ This theoretical 


\section{FEATURE}

underpinning was supplemented by reading the reports of thirty-eight Smart Investing@Your Library programs that ran, or are currently running, in public libraries across the nation..$^{15}$ A partnership between ALA and FINRA, the Smart Investing@Your Library program is the preeminent grantor supporting financial literacy programming, collection development, and staff training in libraries and has awarded 133 grants totaling more than $\$ 10$ million since its launch in $2007 .^{16}$ These competitive grant-supported programs serve as ideal examples of programming nationwide.

The study focused on library collections in the popular personal finance genre by compiling a list of those personal finance books patrons might be most likely to encounter were they to take the ubiquitous step to search the web for reading recommendation. Over the course of several days in September of 2014, the author conducted three Google searches, allowing the search engine to provide auto-fill search phrases based on the beginning keywords of "personal finance books." Accessing all the unique webpages on the first page of each of the Google search results lists (nine results per page, not including sponsored results), the author pulled from these webpages all recommended titles. In total, there were 150 individual book titles included in the search results; the author read each title which appeared on the list more than twice, and examined the content of these books in great depth in a previous article. ${ }^{17}$ The books studied were:

- The Total Money Makeover by Dave Ramsey (twelve search results mentions)

- The Millionaire Next Door by Thomas J. Stanley and William D. Danko (seven mentions)

- Your Money or Your Life by Vicki Robin and Joe Dominguez (five mentions)

- The Intelligent Investor by Benjamin Graham (five mentions)

- Think and Grow Rich by Napoleon Hill (four mentions)

- The Richest Man in Babylon by George S. Clason (four mentions)

- I Will Teach You To Be Rich by Ramit Sethi (four mentions)

- A Random Walk Down Wall Street by Burton G. Malkiel (four mentions)

- Secrets of the Millionaire Mind: Mastering the Inner Game of Wealth by T. Harv Eker (three mentions)

- Rich Dad, Poor Dad by Robert Kiyosaki (three mentions)

- The Money Book for the Young, Fabulous and Broke by Suze Orman (three mentions)

- The Automatic Millionaire by David Bach (three mentions)

There are clear limitations to this research process. Examining RUSA's Financial Literacy Education in Libraries: Guidelines and Best Practices for Service is primarily an exploration of the theoretical ideal of library financial literacy programming, and does not necessarily reflect actual library programming. Even the Smart Investing@Your Library program reports likely convey unusually strong financial literacy programs, as these were the programs which obtained grant funding. It was the author's considered opinion that in choosing a subset of library financial literacy programming to serve as a proxy for a study of the practice as a whole, studying premier programs would not negatively influence the validity of the findings.

In compiling a list of popular personal finance texts, simulating Google searches was deemed to be the most accurate approximation of likelihood of contact with patrons. In exploring the possible interplay between library programming and library financial literacy collections, the author is primarily concerned with those resources library patrons might be most likely to encounter (and thus the resources most likely to interact with library programming through sheer happenstance). Simulated Google search results (which included Amazon Best Seller lists), as opposed to any one authoritative list of "best" books, was judged the most accurate means of obtaining such a list. It is not anticipated that the average searcher would employ the same multistep Google search strategy the author used, but that the author's choice to compile an average results list of individual titles addresses, to the extent possible, the varied results any Google searcher might get for any given single search. In an effort to gauge how likely one would be to find these popular personal finance texts in a US public library, the author searched for each of the twelve chosen titles in the catalogs of ten sample libraries from the Smart Investing@Your Library reports and found an average of eleven of the twelve titles available in the sample libraries. ${ }^{18}$

\section{DISCUSSION}

The examination of the books for this study was undertaken using qualitative content analysis techniques. Content categories and a coding scheme were allowed to emerge from the readings organically and coding was done manually, eventually developing into a basic hierarchy of recurring themes throughout the texts. One overarching theme that emerged in all the books was the asking of a fundamental question: What is the ultimate goal of financial literacy? This is a core question at the root of library programming as well, influencing the target audience, content, and explicit or implicit goals of the programming as seen through the Smart Investing@Your Library reports. After reading and coding the content of the popular personal finance books, the author compared this content to the program descriptions in the Smart Investing@Your Library reports.

Library financial literacy programming and popular personal finance literature appear to address different audiences, content, and goals overall. There is surprisingly little overlap between the target audience that popular personal finance literature addresses, and those audiences targeted by most financial literacy library programming. In addressing these divergent audiences, the personal finance literature and library programs also tend to emphasize different content areas in their coverage. These differences likely reflect, and are further influenced by, differing financial 
and educational objectives between the two mediums and perhaps a fundamentally different focus on action-oriented versus literacy-oriented overarching goals.

The goals of personal finance literature generally extend to true financial literacy only to the extent that they attempt to give readers a sufficient financial understanding to carry out specific actions suggested by the text. Library financial literacy programming, on the other hand, ideally follows the precepts of the RUSA Guidelines, which stipulate that, "Financial literacy programs and workshops should demonstrate how to:

1. Identify, access, and compare financial information from a variety of sources.

2. Critically evaluate the credibility, timeliness, and point of view or bias of financial information and its sources.

3. Apply financial information wisely and productively.

4. Use financial information ethically."19

This emphasis on understanding behind-the-scenes information literacy components ties in with an emphasis on understanding underlying financial concepts and issues beyond everyday financial experiences; in short, achieving true literacy as regards financial concerns. There are, in many regards, more difference between personal finance literature and library financial literacy programming than there are similarities.

\section{TARGET AUDIENCE}

Just looking at the titles of the personal finance books gives one immediate insight into their intended audience: of twelve titles read for this study, seven include the words "millionaire" or refer to being "rich." These are books generally intended for middle and upper middle class readers. The texts support this initial impression. Examples, from basic investment calculations to tips for cutting back living costs, automatically assume readers are at a certain socioeconomic level. Burton G. Malkiel's mathematical examples in A Random Walk Down Wall Street often start with initial investments of $\$ 10,000 .{ }^{20}$ Money market accounts, readers are assured, can be opened with initial investments as low as $\$ 1,000 .{ }^{21}$ Though readers are cautioned mutual funds may require $\$ 1,000$ to $\$ 3,000$ as a minimum to buy in, general assumption is readers can buy them one at a time, and have a full portfolio soon enough. ${ }^{22}$ In The Money Book for the Young, Fabulous and Broke, Suze Orman gives tips for cutting back expenses on the "small stuff." Her suggestions include not dry cleaning clothes that can be washed at home, bringing one's lunch to work "one or two days a week," and buying sporting equipment for things like golf and skiing off-season or used. ${ }^{23}$ In an odd twist on addressing financially betteroff readers, all of the books assume their readers have some significant debt (credit cards, car loans, mortgages), but in general, the stance of these books can be summarized by the claim cried out in David Bach's The Automatic Millionaire: "The problem is not how much we earn ... it's how much we spend!"’24

Library programming, on the other hand, cannot and does not make any such assumption about patrons. Library financial literacy programs are often targeted toward patrons in lower socioeconomic brackets. For these patrons, financial literacy is more complicated than simply learning to control spending; part of the problem for those in poverty is likely that they have real earning issues, as well as potential spending struggles. While the books focus on issues like what to do with stock options, the RUSA Guidelines include references to government assistance programs, and suggest workshop ideas addressing payday and title loans and credit card cash advances, lending avenues unlikely to be widely utilized by the relatively wealthy. ${ }^{25}$ Library programs are frequently focused on topics such as how to obtain a job or how to handle job loss (rather than how to negotiate stock options) and there are even programs being held outside libraries at food pantries and other economic assistance venues. ${ }^{26}$

Library programming also tends to focus on more narrowly defined target audiences within this socioeconomic range. Particularly, many Smart Investing@Your Library programs have targeted women, youth, the elderly, families, and ESL immigrants and refugees. These demographic groups are both less financially literate, on a whole, and also more financially at risk. ${ }^{27}$ It can be argued that women suffer a greater impact from low financial literacy due to the gender pay gap, greater likelihood to take breaks in their careers than men, and a greater average lifespan than men, meaning they tend to require more years of retirement funding and also tend to outlive their spouses. ${ }^{28}$ Women also tend to score lower than their male counterparts on financial literacy assessments, and are far more likely to lack confidence in what financial literacy knowledge they do possess ${ }^{29}$ Library programs to address these issues have included community conversation groups for women to discuss money issues, a retirement planning club for women, and more general financial literacy education marketed around themes like "Your Recipe for Success," under the assumption that cooking is a strongly female-gendered theme. ${ }^{30}$

For addressing youth, the RUSA Guidelines include numerous references to instructing college students on topics such as student loans, grants, and repayment options. ${ }^{31}$ Smart Investing@Your Library programs for the college-age demographic often focus on controlling credit card debt and learning to live on a lean budget.32 For children, the Smart Investing@Your Library programs include financial literacy computer games, replica stores where children can learn to exchange money for goods, story times that incorporate lessons and activities about money, singalong songs about piggy banks, and a "Reality Check" program for older children which simulates a financial reality based on a hypothetical career, family scenario and monthly salary. ${ }^{33}$ The children's room librarian at Richland Public Library in Columbia, SC astutely pointed out that, "A library card is like a first credit card. . . . If you bring 


\section{FEATURE}

books back on time, there's no penalty." ${ }^{34}$ So perhaps financial literacy library programming for children is only making explicit a sort of instruction libraries have been imparting subtly since their founding. It is an area that needs more instruction though. While most young adults will have access to a wide range of financial products before they enter the job market, the fact that vast numbers will graduate college with both credit card and student loan debt may indicate they are not ready to handle their finances wisely. ${ }^{35}$

The Smart Investing@Your Library reports include two examples of libraries providing programming at senior centers and one program attempting to address the issues of identity theft and financial fraud, especially as these issues affect at-risk seniors. ${ }^{36}$ There are also programs that include this elderly demographic, along with all the other age groups, in family focused financial literacy programs. In these programs, parents and children learn about financial issues together and libraries are hopefully positioned as innovators "with a positive message to help families with a touchy subject." ${ }^{37}$ There are also programs focused on teaching parents how to teach their children about finances, potentially facilitating the broader possibility of financial literacy being addressed in the home. ${ }^{38}$ None of the personal finance books read for this study included more than a passing reference to how parents might model financial behaviors or directly instruct their children in these matters. Even Rich Dad, Poor Dad, though it includes many anecdotes of financial lessons Kiyosaki learned from his "rich dad," does not discuss pedagogically how parents can instruct their children in financial literacy matters. This may be an area where library programming should pay particular attention.

English-as-a-second-language programs have been widespread in libraries for quite some time, but it is a recent innovation for libraries to heavily incorporate financial literacy education into this curriculum. ${ }^{39}$ This innovation makes a lot of sense considering the at-risk nature of ESL immigrant and refugee groups. Though the biggest predictors of financial literacy are income and education, the 10-13 percent of US households that do not have bank accounts are predominantly lower income, minorities and/or recent immigrants. ${ }^{40}$ Librarian Paolo Melillo explained of the Orlando, FL Orange County Library system's financial literacy program for immigrants: "They understood the money system in their own country, but not in the U.S." ${ }^{\prime 41}$ Rochester Public Library (Monroe County, NY) targeted their ESL financial literacy programs still more precisely, to address their large local refugee population. "Financial literacy for the refugee community is crucial," an educator with the Consumer Credit Counseling Services of Rochester explained. "Unlike traditional immigrants, many of these people have spent their entire lives in camps where there was no way to earn, save or spend money. They have a much larger learning curve."12 It is not surprising that libraries have taken up the call to serve those most in need of literacy; it is just that these programs represent perhaps an expansion of the types of literacies previously addressed.
None of the books studied particularly address any of these target demographics at length. The author cannot comment on books failing to address ESL individuals, as the only books read for this study were English-language titles found using the English-language version of Google. As well, financial literacy texts for children may be underemphasized by the search method employed for this study, as these resources might have appeared more heavily in results from different Google keyword searches; individuals searching for texts specifically for their children might be likely to include search terms that refer to the desired age group. Comments regarding oversights in the literature reviewed for this study should be considered with these limitations in mind.

Popular personal finance books address their readers as genderless and without a particular ethnic or cultural background, in general. Many books assume there may be families involved in financial situations (five specifically address how to handle financial issues in romantic and/or familial relationships), but the books primarily address the individual reader, whomever he or she may be. ${ }^{43}$ Though age groups are frequently mentioned as regards investment advice, since risk tolerance in the markets is often correlated to age, no particular age group is the focus of any full book read for this study. Ramit Sethi's I Will Teach You to be Rich is the closest thing to an age-targeted book on the list, but Sethi's focus on youth refers mainly to young professionals, which could include a broad age range. Even Suze Orman's The Money Book for the Young, Fabulous and Broke is focused on "young" people that are buying homes and considering their retirement investments. At one point Orman recommends parent-readers add their children as authorized users to a credit card; Orman argues that "once you have a fifteen-year-old, it is your obligation to teach him or her good money habits." ${ }^{\prime 4}$ This means "young" in Orman's title refers to an age range that at the very least includes readers in their thirties, a far cry from the children and teens many of the studied library programs targeted. Less focus on addressing particular demographic groups, especially those disproportionately impacted by financial illiteracy, is a potential oversight in the personal finance genre. In this regard, financial literacy library programming may be addressing a crucial gap in coverage.

\section{CONTENT AND GOALS}

Further coverage differences are found in the content and goals addressed by personal finance literature and library programming respectively. In addition to differing as regards particular content areas covered, the content that is covered varies in its entirety regarding depth of coverage in any and all particular content areas, intellectual barriers to access, and the overarching goals of the two educational mediums. These areas of difference are inexorably intertwined. Depth of coverage can necessitate and indeed become in itself a type of intellectual barrier to access, for example. If 
an author wishes to cover a particular content area in great depth, this likely requires that the book take considerable time building the conceptual foundations itself or else that the author presumes its readers are already in possession of these intellectual foundations. If a particular reader does not possess these intellectual foundations, this presumption becomes a very real barrier to access; the reader cannot make use of this particular book without first obtaining significant background knowledge elsewhere. The depth of coverage and the existence of intellectual barriers to access are characteristics derivative of the overarching goals of the educational mediums in question. Exploring how the goals of the two mediums differ therefore provides insight into differences in content covered, content depth, and intellectual prerequisites.

The goals of financial literacy library programming and personal finance literature differ in two main ways:

1. Whether the ultimate financial goal is to help the audience member achieve financial survival, or financial independence; and,

2. Whether the educational goal is to help the audience members achieve financial fluency, or just the conversational scaffolding necessary to "get by."

The first goal was mentioned earlier in reference to target demographics. While library programming primarily focuses on the financial goal of imminent survival, personal finance books generally focus on the goal of financial independence. Even The Money Book for the Young, Fabulous and Broke clarifies that "we aren't just going to get you past broke, we are going to make sure you never revisit broke.".45 To ensure readers "never revisit broke," personal finance books generally focus beyond imminent financial survival to instilling good financial habits that will build sustainable wealth.

Some of the books explicitly state that their goal is making their readers "rich," but for most the goal pursued is more nuanced, and more significant. Financial independence is a fluid monetary figure based on the spending associated with an individual's lifestyle. While "rich" is a term often defined by a static net worth, financial independence is defined as the point at which "monthly investment income crosses above monthly expenses." ${ }^{.46}$ The goal can therefore be attacked on two fronts. One achieves financial independence through a mix of earning more investment income and cutting down monthly expenses. ${ }^{47}$

Investment income is what the books would term "passive" income and it is the Holy Grail of personal finance. Passive income is any income for which you do not need to actively work. The RUSA Guidelines mention "business income" under "Earnings Guidelines," but limit their discussion mainly to "rent from investment properties or profits from a business." ${ }^{\text {"48 }}$ Though there is a whole section devoted to the saving and investing in the RUSA document, and understanding both "debt-based investments" and "equity-based investments" are stated potential program outcomes for this content area, nowhere is passive income mentioned, nor is it conveyed that library programs may wish to emphasize that passive income need not be reserved for some far-off retirement, but is actually a potential means to achieve financial freedom at any point in time. ${ }^{49}$ As soon as one can cut monthly expenses low enough, and save and invest enough to earn a monthly passive income stream to cover those lowered expenses, the individual need never work another day in his or her life..$^{50}$ This is the ultimate financial goal of most of the personal finance literature.

One can relate these differing goals back to the different audiences of the two educational mediums: Assuming a middle-class audience, the books can exhort their readers to move beyond financial survival to a lifestyle fully supported by investment assets. The target audience of library programming, on the other hand, likely struggles to pay for all their necessary expenses; they may have no surplus with which to purchase investment assets. While the RUSA Guidelines mention various investment vehicles by name and state that library patrons should be able to "compare financial investments like stocks and bonds to alternatives like real estate and gold," the Smart Investing@Your Library programs show a predominant focus in practice primarily on imminent financial survival rather than long-term investments. ${ }^{51}$

The books would argue that investing is a necessary expense, and that it is the cornerstone of financial survival, both imminent and long-term. "Pay yourself first" is a phrase that is never mentioned in either the RUSA Guidelines or the Smart Investing@Your Library reports, but it is the absolute heart of popular personal finance literature. The concept was first articulated in 1926 in George S. Clason's book of financial parables, The Richest Man in Babylon. The concept turns most monthly financial realities on their head; instead of saving and/or investing what is left over after one has paid all his or her bills for the month, the individual automatically takes out monthly savings/investment money at the beginning of the month..$^{52}$ Many of the personal finance books expand on this idea, perhaps most vividly David Bach who points out that if we are only saving 5 percent of our income on average, then "most of us work barely 22 minutes a day for ourselves." ${ }^{.53}$ Instead we are working for the utility company, the grocer, the car dealership; we are working to pay the bills, instead of funding our future. It would only seem fair that, "A part of all you earn is yours to keep," but this isn't the reality for most. ${ }^{54}$ Certainly putting aside more than 5 percent of their income before paying for their necessities is beyond reckoning for some library patrons targeted by financial literacy programming. Yet, the financial pundits in popular personal finance literature hold to this maxim so fiercely that Robert T. Kiyosaki, for instance, describes dire circumstances where he faced unpaid bills, or even the IRS, yet he insisted on paying himself first. ${ }^{55}$ Libraries will have to consider: Where does one realistically prioritize survival today vs. survival in retirement? Certainly financial literacy programming or resources that include the potential, 


\section{FEATURE}

misinterpreted takeaway that one shouldn't pay their bills are walking a nerve-wracking line. Yet, if patrons fail to find funds to save and invest, are they only exchanging survival today for a dire financial future?

There are also concepts conspicuously absent from the personal finance literature that the RUSA Guidelines recommend covering. The concept of "time-value of money" is a prime example. ${ }^{56}$ The fact that none of the twelve books read for this study explicitly articulated this concept brings us to the differing educational goals of the two mediums. Some books do insist on financial fluency, most notably the heavy-investment books: The Intelligent Investor by Benjamin Graham and A Random Walk Down Wall Street by Burton G. Malkiel. Malkiel even insists his readers must understand the sources of investment information, so that they can continue to consult these educational resources regularly as they continue to employ his investment advice. ${ }^{57}$ But these two investment books are the exception to the general rule for popular personal finance literature: for the most part the educational goals of personal finance literature only extend to the point of giving readers enough financial background that they can carry out the specific advice laid out in the text. Some books even take this to the extreme of providing what amount to scripts so readers can ask particular salient questions, of potential brokers, for example, or the credit card company, and listen for particular keywords or numbers in return. ${ }^{58}$

Library programming, on the other hand, focuses very much on the literacy component of financial literacy. Library programming guidelines include possible workshop topics like understanding "Where do my tax dollars go?" or potential program outcomes like "Understand the time-value relationship of money and how it affects debt repayment." 59 Understanding where and how one's taxes will be utilized or how we calculate and consider net present value of money in financial decision-making is not essential to robotically carry out financial advice. But library programming wants to do more than convince patrons to carry out specific financial actions; the emphasis is on helping patrons achieve true literacy. The word "understand" appears eighty-four times in the RUSA Guidelines. ${ }^{60}$ While personal finance literature and library financial literacy programming may cover some similar content areas, the fundamental focus is on inherently different financial and educational outcomes.

This is not to say that personal finance books cannot contribute to library programming, or serve as a means of continuing self-education and debate. Napoleon Hill's Think and Grow Rich or Harv T. Eker's Secrets of the Millionaire Mind would provide an interesting spiritual take on a program addressing the RUSA "Earning Guideline" topics. A Random Walk Down Wall Street and/or The Intelligent Investor cannot be beat for in-depth studies of the market and/or investment strategies and theories. Ramit Sethi's I Will Teach You to be Rich would be an invaluable resource to a program targeted at young professionals and Suze Orman's The Money Book for the Young, Fabulous and Broke might be a great fit for a young parent to read. Both Sethi and Orman's books would also provide an interesting debate to any library program recommending traditional budgeting; both books outright decry this practice. ${ }^{61}$ Robin and Dominguez's Your Money or Your Life and Dave Ramsey's The Total Money Makeover will provide great discussion fodder for any program aligning with RUSA Guideline 2.0: "Borrowing and Credit" as both take bold stances regarding credit and debt. ${ }^{62}$ The Millionaire Next Door by Stanley and Danko might be the perfect accompaniment to a Spending Guideline program, as the text devotes quite a bit of time to exploring how wealthy individuals actually tend to be quite frugal when it comes to consumer spending, and David Back's The Automatic Millionaire could introduce program participants to automating their saving and investing before they start spending anything at all on consumer products..$^{63}$ Lastly, George S. Clason's The Richest Man in Babylon is a foundational text for anyone interested in any aspect of financial literacy, but it does spend some particular time exploring issues of financial risk, and so might be particularly suited to accompany a library program addressing RUSA Guideline 5.0: "Protecting Against Risk." ${ }^{164}$

Librarians must always bear in mind, however, that the audiences addressed by personal finance books and library programming, as has been explored herein, are often dissimilar. Librarians should consider the particular patron in question and whether the financial discussions within the text will match that patron's level of background knowledge and current financial situation (if these characteristics are known). As important as programming is, as information experts, being able to introduce patrons to reliable and useful resources is equally important and one thing libraries bring to the financial literacy movement that no other community organization can. ${ }^{65}$ Discovering books more suited to the majority target demographics of library programming may be a prime area for future research.

Librarians might also want to consider whether the books' more practical approach to financial literacy has merits. No doubt librarians will hold strong to the information literacy components of programming, but it might be wise to stop to consider at what point insisting on theoretical understanding detracts from the likelihood that patrons will take action. While some books tout potentially worrisome principles like "Ready, fire, aim!," a middle ground, like "The 85 Percent Solution" might be worth considering in programming. ${ }^{66}$ As Sethi counsels his readers: "Too many of us get overwhelmed thinking we need to manage our money perfectly, which leads us to do nothing at all. That's why the easiest way to manage your money is to take it one step at a time-and not worry about being perfect. I'd rather act and get it 85 percent right than do nothing. ${ }^{{ }^{67}}$ While RUSA's Financial Literacy Education in Libraries: Guidelines and Best Practices for Service is inherently focused on The 100 Percent Solution (ideal workshop topics and program outcomes) actual library programs should bear in mind that educational goals that include "take action" may be more closely aligned with real world financial outcomes. 


\section{CONCLUSION}

This study builds on the scholarly literature and library guidelines and recommendations for financial literacy, concluding that there is not nearly as much overlap in audiences, coverage, or goals between existing popular financial literacy materials and library programming as one might presume. Libraries can rest assured that programming is covering crucial gaps in available financial education resources. At least among this study's proxy group of personal finance books, there were none addressing specifically socioeconomically disadvantaged women, youth, elderly individuals, families or ESL immigrants or refugees. Library programming may also be addressing a different audience in terms of patrons who simply would not have checked out library materials on the topic. The Los Angeles Public Library took a survey as part of their Smart Investing@Your Library grant, and found that among their patrons " $53 \%$ said they had never checked out library materials on financial matters, yet $77 \%$ said they would attend a finance-related workshop at the library." 68

Library programs also have the advantages of flexibility and creativity. Programs do not even need to be ostensibly focused on financial literacy to include components within a broader (and potentially more appealing) context. Ada Community Library in Boise, ID, for instance, had great success with a "free shred day" program that provided informal information on identity theft. ${ }^{69}$ Estes Valley Public Library District (Estes Park, CO) brought in patrons otherwise unlikely to discuss financial literacy by hosting movie nights, playing such titles as Confessions of a Shopaholic and The Pursuit of Happiness and framing a financial literacy discussion around the themes in these popular films. ${ }^{70}$ Many Smart Investing@Your Library grantees found great success having parties or holding fairs focused on financial literacy, but emphasizing the entertainment aspect of their activities. ${ }^{71}$ This is an area that might benefit from further research. How can libraries best address patrons who might not check out financial materials, but could potentially be interested in finance workshops at the library? What are best practices not only for financial literacy programming, but for integrating financial literacy concepts into broader programming?

Particular content covered between library financial literacy programming and personal finance literature varies as widely as the audiences addressed, likely due in part to these differing audiences, assumptions made about the prerequisite knowledge these users may have gleaned elsewhere, and also due to differing financial and educational goals. Even as regards topics universally covered by both personal finance literature and library financial literacy programming, such as retirement planning and budgeting, the exact discussion varies and thus so do the conclusions reached. Financial literacy library programming, for example, frequently recommends traditional budgeting. ${ }^{72}$ Many personal finance books, on the other hand, veer away from traditional budgets, recommending automatic bill payments and other means to guide one's spending. ${ }^{73}$ Ultimately this brings us back to the differing financial goals of the two educational mediums; traditional budgeting is focused on getting users to the point of solvency, while automating one's finances might allow him or her to strategically direct the flow of income to more ambitious goals.

The fact that libraries address foundational knowledge, and sometimes simpler financial topics than the personal finance books, sets up libraries in their usual role as providers of universal access to knowledge. While the personal finance literature may have intellectual barriers to access, library financial literacy programs may be the ideal vehicle to help patrons overcome these barriers. Library financial literacy programming will teach the foundational concepts, while personal finance literature may then expand on these concepts and explore particular issues in greater depth. This connection might be explored through library financial literacy programs that leave participants with recommended reading lists. The utility of this practice might be another good topic for future research.

Libraries should also consider that there are drawbacks purely to the medium of books vs. live programming and libraries might take advantage by playing to the strengths of a live medium. The RUSA Best Practices, for instance, recommend, "As libraries prepare and present financial literacy programs and workshops, an essential step in the process should be the verification of the currency of the content." ${ }^{74}$ Updating content is not something a book can do (other than through the long process of publishing a new edition), while library programming can be relatively easily updated. Similarly, one of the pieces of advice one might glean from the Smart Investing@Your Library case studies is that libraries should "be prepared to modify programming assumptions when users want a different level of learning." ${ }^{75}$ Just as they cannot update their content, neither can books modify their level of content. Books are a static medium. Library programming is dynamic. While there is very clearly a role for both library programming and personal finance literature in the nationwide financial literacy movement, libraries should take pride in providing initial access to content the books don't necessarily cover; addressing audiences the books don't necessarily consider; dynamically adjusting content, coverage and appeal; and pursuing the ultimate goal of financial literacy for those truly most in need.

\section{References}

1. Carlo de Bassa Scheresberg, "Financial Literacy and Financial Behavior among Young Adults: Evidence and Implications," Numeracy: Advancing Education In Quantitative Literacy 6, no. 2 (2013): 1; Financial Industry Regulatory Authority Investor Education Foundation (FINRA), Financial Capability in the United States: Report of Findings from the 2012 National Financial Capability Study (2013): 6, www.usfinancialcapability.org /downloads/NFCS_2012_Report_Natl_Findings.pdf.

2. Organisation for Economic Cooperation and Development (OECD), "Household Spending at Constant US Dollars," Household Final Consumption Expenditure at the Price Levels and PPPs of 2005, accessed August 11, 2016, www 


\section{FEATURE}

.oecd-ilibrary.org/economics/household-spending-at-constant -us-dollars_2074384x-table15; Organisation for Economic Cooperation and Development (OECD), "Household Saving Rates-Forecasts," Economics: Key Tables from the OECD, accessed August 11, 2016, www.oecd-ilibrary.org/economics /household-saving-rates-forecasts_2074384x-table7.

3. Federal Reserve Bank of St. Louis (FRED), "Personal Saving Rate," Economic Research, accessed July 29, 2015, https:// research.stlouisfed.org/fred2/series/PSAVERT.

4. Council for Economic Education, Survey of the States: Economic and Personal Finance Education in our Nation's Schools (2014): 7, www.councilforeconed.org/wp/wp-content /uploads/2014/02/2014-Survey-of-the-States.pdf.

5. Robert T. Kiyosaki with Sharon L. Lechter, Rich Dad, Poor Dad: What the Rich Teach Their Kids about Money That the Poor and Middle Class Do Not (New York: Warner, 1998), 14.

6. Suze Orman, The Money Book for the Young, Fabulous and Broke (New York: Riverhead, 2005), 218.

7. Margaret Monsour, "Libraries Innovate With New Financial Education Programs," Public Libraries 51, no. 2 (March/April 2012): 37

8. Catherine Arnott Smith and Kristin Eschenfelder, "Public Libraries in an Age of Financial Complexity: Toward Enhancing Community Financial Literacy," The Library Quarterly 83, no. 4 (October 2013): 301; Ashley E. Faulkner, "A Systematic Review of Financial Literacy as a Termed Concept: More Questions Than Answers," Journal of Business and Finance Librarianship 20, no. 1-2 (2015): 8; Federal Bank of Chicago, "About Us," Money Smart Week, accessed August 11, 2016, www.moneysmartweek .org/about; US Department of the Treasury, "Financial Literacy Education Commission," Resource Center, accessed August 11, 2016, https://www.treasury.gov/resource-center/financial -education/Pages/commission-index.aspx.

9. Udo Reifner and Isabel Herwig, "Consumer Education and Information Rights in Financial Services," Information \& Communication Technology Law 12, no. 2 (2003): 125-42; Molly A. Wolfe-Hayes, "Financial literacy and education: An Environmental Scan," International Information \& Library Review 42, no. 2 (2010): 105-10; Sonja Špiranec, Mihael Banek Zorica, and Gordana Stoki Simončić, "Libraries and Financial Literacy: Perspectives from Emerging Markets," Journal of Business $\&$ Finance Librarianship 17, no. 3 (2012): 262-78; Monsour, "Libraries Innovate With New Financial Education Programs," 36-43; Smith and Eschenfelder, "Public Libraries in an Age of Financial Complexity: Toward Enhancing Community Financial Literacy," 299-320.

10. Molly A. Wolfe-Hayes, "Financial Literacy and Education: An Environmental Scan," The International Information \& Library Review 42, no. 2 (2010).

11. Margaret Monsour, "Libraries Innovate With New Financial Education Programs," Public Libraries 51, no. 2 (March/April 2012).

12. Catherine Arnott Smith and Kristin Eschenfelder, "Public Libraries in an Age of Financial Complexity: Toward Enhancing Community Financial Literacy," Library Quarterly 83, no. 4 (October 2013)

13. Reference and User Services Association (RUSA), Financial Literacy Education in Libraries: Guidelines and Best Practices for Service (Chicago: RUSA, 2014), 18.

14. Ibid., 1-35.

15. American Library Association and FINRA Foundation, "Model Programs," Smart investing@your library, accessed July 29, 2014, http://smartinvesting.ala.org/model-programs.

16. FINRA, "Smart investing@your library," Grants, accessed July 29, 2015, www.finrafoundation.org/grants/library.

17. Ashley E. Faulkner, "Financial Literacy Education in the United States: Exploring Popular Personal Finance Literature," Journal of Librarianship and Information Science: Online First (November 20, 2015), http://dx.doi.org/10.1177/0961000615616106.

18. The ten libraries are Brooklyn Public Library, https://brook lyn.bibliocommons.com; Chesterfield County Public Library, http://library.chesterfield.gov; Estes Valley Public Library District, http://estesvalleylibrary.org; Georgetown Public Library, http://georgetowncountylibrary.sc.gov; Middle Country Public Library, www.mcplibrary.org; Multnomah County Library, https://catalog.multcolib.org; Naperville Public Library, www naperville-lib.org; Pelham Public Library, www.pelhamlibrary .com; Richland Library, www.richlandlibrary.com; York County Library System, www.yorklibraries.org.

19. Reference and User Services Association (RUSA), Financial Literacy Education in Libraries: Guidelines and Best Practices for Service, 2

20. Burton G. Malkiel, A Random Walk Down Wall Street (New York: Norton, 2010), 17.

21. David Bach, The Automatic Millionaire: A Powerful One-Step Plan to Live and Finish Rich (New York: Broadway, 2004), 143.

22. Ramit Sethi, I Will Teach You To Be Rich (New York: Workman, 2009), 183, 194.

23. Orman, The Money Book for the Young, Fabulous and Broke, 155.

24. Bach, The Automatic Millionaire, 31.

25. Orman, The Money Book for the Young, Fabulous and Broke, 251; RUSA, Financial Literacy Education in Libraries: Guidelines and Best Practices for Service, 3, 5, 6 .

26. Carrie Herrmann, "Boone County Public Library," Smart investing@your library, http://smartinvesting.ala.org/lessons-learned /boone-county-public-library; Nelly Somerman, "Schaumburg Township District Library," Smart investing@your library, http:// smartinvesting.ala.org/lessons-learned/schaumburg-township -district-library; Deborah McCullough, "The Public Library of Youngstown \& Mahoning County," Smart investing@your library, http://smartinvesting.ala.org/lessons-learned/the-public -library-of-youngstown-mahoning-county.

27. Jodi Jarecke, Edward W. Taylor, and Tahira K. Hira, "Financial Literacy Education for Women," New Directions for Adult and Continuing Education 141 (Spring 2014): 38; Aimee Picchi, "Women Trail Men in Financial Literacy," Moneywatch (December 31, 2014), www.cbsnews.com/news/the-troubling-financial -literacy-gap-for-women; de Bassa Scheresberg, "Financial Literacy and Financial Behavior among Young Adults," 1-2, 10-11; Wolfe-Hayes, "Financial Literacy and Education," 107.

28. Jarecke, Taylor, and Hira, "Financial Literacy Education for Women," 38; Picchi, "Women Trail Men in Financial Literacy."

29. Picchi, "Women Trail Men in Financial Literacy"; de Bassa Scheresberg, "Financial Literacy and Financial Behavior among Young Adults: Evidence and Implications," 10.

30. Liz Doucett, "Curtis Memorial Library," Smart investing@your library, http://smartinvesting.ala.org/lessons-learned/curtis -memorial-library; Susan Becam, "Newton Free Library," Smart investing@your library, http://smartinvesting.ala.org/lessons -learned/newton-free-library; Lee Turza, "Greenville County Library System," Smart investing@your library, http://smart investing.ala.org/lessons-learned/greenville-county-library -system.

31. RUSA, Financial Literacy Education in Libraries: Guidelines and Best Practices for Service, 7.

32. Phil Clark, "Pioneer Library System," Smart investing@your library, http://smartinvesting.ala.org/lessons-learned/pioneer -library-system; Brian Barrett, "Carmel-Clay Public Library," Smart investing@your library, http://smartinvesting.ala.org /lessons-learned/carmel-clay-public-library.

33. Tracy Delgado-La Stella, "Middle Country Public Library," Smart investing@your library, http://smartinvesting.ala.org/lessons -learned/middle-country-public-library; Paula Gilbert, "York County Library System," Smart investing@your library, http:// 
smartinvesting.ala.org/lessons-learned/york-county-library -system; Heather McCue, "Richland Library," Smart investing@ your library, http://smartinvesting.ala.org/lessons-learned/rich land-library; Barbara Roberts, "Pelham Public Library," Smart investing@your library, http://smartinvesting.ala.org/lessons -learned/pelham-public-library.

34. Heather McCue, "Richland Library."

35. de Bassa Scheresberg, "Financial Literacy and Financial Behavior among Young Adults," 1-2.

36. Polli Ken, "Lawrence Public Library," Smart investing@your library, http://smartinvesting.ala.org/lessons-learned/lawrence -public-library; Sarah Mead, "Multnomah County Library," Smart investing@your library, http://smartinvesting.ala.org /lessons-learned/multnomah-county-library.

37. Nanci Clary, "Chesterfield County Public Library," Smart investing@your library, http://smartinvesting.ala.org/lessons-learned /chesterfield-county-public-library; Herrmann, "Boone County Public Library."

38. Mead, "Multnomah County Library"; McCue, "Richland Library."

39. Becam, "Newton Free Library."

40. de Bassa Scheresberg, "Financial Literacy and Financial Behavior among Young Adults," 10-11; Wolfe-Hayes, "Financial Literacy and Education," 107.

41. Paolo Melillo, "Orange County Library System," Smart investing@your library, http://smartinvesting.ala.org/lessons-learned /orange-county-library-system.

42. Jennifer Byrnes, "Rochester Public Library," Smart investing@ your library, http://smartinvesting.ala.org/lessons-learned-roch ester-public-library.

43. Vicki Robin and Joe Dominguez, Your Money or Your Life: 9 Steps to Transforming Your Relationship with Money and Achieving Financial Independence (New York: Penguin, 2008), 287; Orman, The Money Book for the Young, Fabulous and Broke, 271, 323-54; Thomas J. Stanley and William D. Danko, The Millionaire Next Door: The Surprising Secrets of America's Wealthiest (New York: Pocket, 1996), 37, 80; Ramit Sethi, I Will Teach You To Be Rich, 223-29; T. Harv Ecker, Secrets of the Millionaire Mind: Mastering the Inner Game of Wealth (New York: Harper Business, 2005), 36-39.

44. Orman, The Money Book for the Young, Fabulous and Broke, 47.

45. Ibid., 13.

46. Robin and Dominguez, Your Money or Your Life, 243.

47. Faulkner, "Financial Literacy Education in the United States," $12-13$.

48. RUSA, Financial Literacy Education in Libraries: Guidelines and Best Practices for Service, 4

49. RUSA, Financial Literacy Education in Libraries: Guidelines and Best Practices for Service, 8-10.

50. Robin and Dominguez, Your Money or Your Life, 243; Ecker, Secrets of the Millionaire Mind, 157.

51. RUSA, Financial Literacy Education in Libraries: Guidelines and Best Practices for Service, 10; Delania Adkins, "Pike County Public Library," Smart investing@your library, http://smartinvesting .ala.org/lessons-learned/pike-county-public-library; John Hurley, "Apache Junction Public Library," Smart investing@your library, http://smartinvesting.ala.org/lessons-learned/apache -junction-public-library; Carrie Herrmann, "Boone County Public Library"; Clary, "Chesterfield County Public Library"; Steven Backs, "Monroe County Public Library," Smart investing@your library, http://smartinvesting.ala.org/lessons-learned/monroe -county-public-library; Roberts, "Pelham Public Library"; Byrnes, "Rochester Public Library."

52. George S. Clason, The Richest Man in Babylon (New York: Plume, 1955), 26.

53. Bach, The Automatic Millionaire, 71.

54. Clason, The Richest Man in Babylon, 26.

55. Kiyosaki with Lechter, Rich Dad, Poor Dad, 175.

56. RUSA, Financial Literacy Education in Libraries: Guidelines and Best Practices for Service, 9

57. Malkiel, A Random Walk Down Wall Street, 402-3.

58. Bach, The Automatic Millionaire, 145-46, 201.

59. RUSA, Financial Literacy Education in Libraries, 4, 7.

60. Ibid., 1-35.

61. Sethi, I Will Teach You To Be Rich, 92-93; Orman, The Money Book for the Young, Fabulous and Broke, 146.

62. RUSA, Financial Literacy Education in Libraries, 5

63. Ibid., 11.

64. Ibid., 13

65. Mead, "Multnomah County Library."

66. Ecker, Secrets of the Millionaire Mind, 81; Sethi, I Will Teach You To Be Rich, 8.

67. Sethi, I Will Teach You To Be Rich, 8 .

68. Youngsill Lee, "Los Angeles Public Library," Smart investing@ your library, http://smartinvesting.ala.org/lessons-learned/los -angeles-public-library.

69. Mary DeWalt, "Ada Community Library," Smart investing@ your library, http://smartinvesting.ala.org/lessons-learned/ada -community-library.

70. Kurtis Kelly, "Estes Valley Public Library District," Smart investing@your library, http://smartinvesting.ala.org/lessons-learned /estes-valley-public-library-district.

71. Dwight McInvaill, "Georgetown Public Library," Smart investing@your library, http://smartinvesting.ala.org/lessons-learned /georgetown-public-library; Kent Palmer, "Naperville Public Library," Smart investing@your library, http://smartinvesting .ala.org/lessons-learned/naperville-public-library; Sheila Burnett, "San Diego Public Library," Smart investing@your library, http://smartinvesting.ala.org/lessons-learned/san-diego-public -library-2.

72. Nikki Maounis, "Camden Public Library," Smart investing@your library, http://smartinvesting.ala.org/lessons-learned/camden -public-library; Nanci Clary, "Chesterfield County Public Library; Ken, "Lawrence Public Library"; Backs, "Monroe County Public Library"; Byrnes, "Rochester Public Library"; Burnett, "San Diego Public Library."

73. Ramit Sethi, I Will Teach You To Be Rich, 92-93; Suze Orman, The Money Book for the Young, Fabulous and Broke, 146; David Bach, The Automatic Millionaire, 59.

74. RUSA, Financial Literacy Education in Libraries, 18

75. Palmer, "Naperville Public Library." 